\title{
Perdebatan Teori Transisi Demokrasi
}

\author{
Zeffry Alkatiri
}

\begin{abstract}
This paper discusses the debate on the theories of democratic transition that has been going on since the 1960s. Democratic thoughts area always related to a context of change in a society. The theories of democratic transition had come to be debated again when the communist block countries and Russia changed their ideology and entered a democratic transition process. This debate provide a reference point and comparative framework that can be employed to evaluate socio-political changes in other countries that are experiencing similar democratic transition process and all of the consequences and challenges it poses.
\end{abstract}

KEYWORDS theory of democratic transition, ideology

Fenomena transisi demokrasi mulai marak sejalan dengan terjadinya perubahan sosial politik sekitar dekade tahun 1980-an di Eropa Timur. Beberapa negara seperti Hongaria, Polandia, dan Chekoslavakia berhasil menumbuhkan semangat demokrasi dalam masyarakatnya. Pemberdayaan demokrasi di negara tersebut didasarkan atas keinginan untuk melepaskan diri dari kooptasi dan hegemoni negara yang terlalu memonopoli kehidupan mereka semasa rezim komunis berkuasa. Hal yang sama kemudian juga terjadi di negara Uni Sovyet (Rusia). Di tengah gencarnya teknologi komunikasi, pemerintah Uni Sovyet tidak dapat lagi menahan arus informasi dari berbagai arah. Arus informasi itu memengaruhi masyarakat dan membentuk opini publik yang mendewasakan cara berpikir dan meluaskan wawasan, sehingga sebagian dari mereka menjadi terbuka untuk mengoreksi masyarakat dan negaranya. Terjadinya perubahan itu dibarengi dengan perubahan status kenegaraan dan kemasyarakatan di beberapa negara di atas. Kenyataan itu terlihat pada konstitusi mereka yang berbeda dengan konstitusi model komunis yang lama. Konstitusi yang baru memperlihatkan adanya kesadaran untuk memasukan konsepsi demokrasi dalam pasal-pasalnya.

Akan tetapi, implementasi dari konstitusi baru yang mengarah pada perbaikan sistem pemerintahan dan demokrasi, tampaknya masih belum dapat dioperasionalkan dengan baik. Ada beberapa alasan terhambatnya oparasionalisasi itu, di antaranya karena masih bertahannya sistem dan nilai-nilai lama, seperti birokratisme, patronisme, dan nepotisme. Fenomena tersebut merupakan hal yang dianggap lazim dalam masyarakat yang sedang memasuki transisi demokrasi. 
Konstitusi baru di negara Eropa Timur dan Rusia membuat pilihan dilematis bagi masyarakatnya. Di satu sisi sistem baru itu ternyata belum siap menampung aspirasi masyarakat yang ada. Di sisi lain, sebagian masyarakatnya sendiri juga belum siap untuk menerima perubahan yang terjadi. Dalam kondisi seperti itu, terjadi konflik antara sebagian masyarakat yang menginginkan perubahan cepat dengan sebagian masyarakat yang menginginkan perubahan secara bertahap. Kondisi demikian itu, secara tidak langsung telah menimbulkan krisis multi dimensi dan krisis legitimasi di masyarakatnya yang mengakibatkan munculnya kesenjangan sosial, ketidakpastian hukum, ketidakstabilan, dan ketidakpercayaan masyarakat pada pemerintahnya. Kondisi itu diakibatkan salah satunya oleh pranata hukum yang belum mampu untuk direalisasikan. Kondisi demikian telah mempersulit gerak ruang publik dan pemerintahan serta juga mengakibatkan tidak terbentuknya masyarakat politis yang menjadi esensi dari masyarakat demokrastis yang partisipatif. Umumnya pada masa transisi tersebut yang menjadi perhatian utama pemerintah adalah pemulihan ekonomi dan politik, sedangkan faktor lain, seperti Hak Asasi Manusia (HAM) dan lainnya belum sempat diperhatikan. Berdasarkan kondisi realitas itu tumbuhlah beragam pemikiran tentang proses transisi demokrasi di berbagai negara di atas. Disadari bahwa transisi demokrasi membutuhkan waktu dan akan menghadapi berbagai kendala dalam pelaksanaannya. Berbagai pemikiran seperti itu akan dikemukakan di bawah ini.

\section{TinjAUAN TeORi Demokr asi}

Transisi dalam konteks regenerasi politik berarti semua anggota masyarakat yang sudah dewasa mendapat kesempatan untuk mengambil peran dalam penyelenggaraan negara. Di sisi lain, transisi dalam konteks sosial berarti juga proses yang mengarah pada berbagai bentuk perubahan masyarakat dan proses perubahan terjadi dari nilai lama ke nilai yang baru, sedangkan demokratisasi berarti adanya proses perubahan wacana identitas dalam struktur masyarakat dan anggota masyarakat lain dapat berperan dalam kehidupan politiknya. Demokratisasi juga merupakan suatu proses yang mengarah kepada pembentukan demokrasi (Anderson 2001: 98, 105, dan Meyer 2002).

Berdasarkan penelitian lapangan di beberapa negara yang sedang memasuki transisi demokrasi diperoleh kenyataan bahwa dalam masa transisi demokrasi sering terjadi proses tawar menawar antara para elite partai dengan kelompok yang berkuasa yang mengarah pada persetujuan bersama atau sebaliknya (Anderson 2001: 23 -24). Pada transisi demokrasi di negara Eropa Timur dan Rusia terjadi tawar menawar yang mengarah kepada perubahan dari model otoritarian-totalitarian kepada demokrasi. Akan tetapi dalam praktiknya masih terdapat pengaruh model otoritarian, yakni adanya kekuasaan Presiden yang dominan dibanding dengan dua lembaga negara lainnya. Proses tawar menawar, akhirnya menghasilkan konsensus 
baru yang dalam prosesnya pun terus dikonsolidasikan dalam berbagai cara dengan para elite yang berkepentingan.

Anderson (2001) pernah membicarakan konsolidasi demokrasi dalam struktur para elite politik pada kasus transisi demokrasi Rusia. Dalam kesimpulannya disebutkan bahwa walaupun demokrasi berjalan tersendat, tetapi konsolidasi para elite dapat terlaksana, dibanding dengan negara pascakomunis lainnya. Alasannya, walaupun banyak ditemukan kasus penyelewengan, para elite masih tetap mengacu pada konsensus yang ada. Tulisan Hanson merupakan jawaban terhadap Schider (1998) yang menyatakan bahwa demokrasi di Rusia tidak terkonsolidasi dengan baik seperti yang dilihatnya dari fenomena kepartaian dan kelompok elite politik yang saling bertentangan (Anderson 2001:34). Akan tetapi pada kenyataannya terdapat gejala umum bahwa para elite di Rusia setelah referendum konstitusi baru tahun 1993, masih terus terpecah-pecah menjadi beberapa fraksi dan kelompok yang saling bertentangan. Dalam konteks demokrasi peran para agensi akan selalu saling berkaitan. Para agensi yang dimaksud adalah partai dari kelompok revolusioner, gerakan kelompok separatis etno-nasionalis, gerakan kelompok militer, presiden yang potensial, dan intervensi militer pihak asing (Anderson 2001: 60).

Dalam konteks demokrasi, ornop (organisasi non-pemerintah) juga merupakan salah satu agen demokrasi yang perlu diperhitungkan. Ornop merupakan salah satu pilar demokrasi, di samping lembaga eksekutif, legislatif, yudikatif, media massa, dan mahasiswa. Mereka berperan sebagai agensi dalam konteks demokrasi, sekaligus sebagai pengontrol demokrasi. Dalam sistem demokrasi sangat diperlukan agensi untuk menyelesaikan berbagai konflik yang muncul. Agensi tersebut dapat berasal dari pengacara, partai, dan juga ornop. Berjalan tidaknya suatu proses demokrasi dapat dilihat dari adanya peran para agensi yang terdapat di dalamnya. Jika keberadaan para agensi dikooptasi oleh suatu rezim pemerintahan, maka proses demokrasi di suatu negara belum berjalan dengan baik. Proses demokrasi tidak berjalan dengan baik karena tidak memberikan dan membuka ruang serta peluang bagi para negosiator dan pengacara untuk bekerja. Konsekuensi memasuki era transisi demokrasi, berakibat juga pada pemberian dan penyediaan peluang atau ruang gerak partisipasi bagi para agensi itu. Ruang gerak untuk berpartisipasi bukan hanya diberikan oleh suatu rezim pemerintahan, melainkan juga dapat diberikan atas keinginan dari masyarakatnya. Dalam hal ini, suatu masyarakat, kelompok, ataupun komunitas yang umumnya dominan dapat perduli, tetapi dapat juga sebaliknya, yakni menolak terhadap kehadiran peran suatu agensi dalam kehidupan mereka.

Fenomena itulah yang membedakan antara partisipasi dalam sistem pemerintahan otoritarian-totalitarian dengan demokrasi. Dalam negara demokrasi, pemerintah sudah seharusnya memberikan kepada masyarakat suatu kesempatan untuk berpartisipasi (peluang) dalam proses pembuatan suatu keputusan politik, sedangkan dalam pemerintahan otoritarian- 
totalitarian, negara memberikan tugas pokok kepada masyarakat sebagai bentuk partisipan dan perintah (Almond dan Sidney, 1984: 3). Sementara itu, otoritarian maupun totalitarian yang dimaksud jelas merupakan kategori terbalik dari demokrasi dan diartikan sebagai demokrasi yang bersifat tidak demokratis (Anderson 2001:1).

\section{Pentingnya Faktor Kesejarahan dan Budaya Politik}

Pola pikir suatu bangsa umumnya terbentuk dari berbagai unsur yang saling memengaruhi. Salah satunya adalah latar belakang sejarah. Faktor sejarah mempunyai dampak khusus bagi suatu bangsa, sebab di dalam sejarah terjadi berbagai proses pergulatan yang dapat saja berdampak positif, bahkan juga negatif bagi bangsa tersebut. Selain itu, proses sejarah juga dapat membentuk kerangka ideologi, pola kelakuan, nilai budaya, mitos, dan budaya politik suatu bangsa.

Budaya politik merupakan seperangkat pengetahuan, gagasan, dan sentimen politik yang terdapat pada suatu masyarakat, suatu wilayah, dan pada periode tertentu. Selain itu budaya politik memperlihatkan cara pewarisan pengetahuan, gagasan, dan "sentimen" dari suatu generasi ke generasi berikutnya dalam suatu masyarakat. Budaya politik dapat membentuk mentalitas suatu masyarakat. Atau sebaliknya, mentalitas suatu masyarakat dibentuk dan berasal dari budaya politik yang telah mentradisi (Burke 2001: 115).

Almond dan Sidney melihat, bahwa budaya politik dapat berupa kombinasi antara pandangan modern dengan klasik yang dapat menjadi suatu strategi budaya yang secara tidak langsung dapat memberi kesempatan berlangsungnya perubahan sekaligus melunakannya. Dalam budaya politik akan tercakup pembicaraan mengenai sistem politik, orientasi politik, dan sikap politik yang diinternalisasikan ke dalam kesadaran masyarakatnya atau mentalitasnya (Almond dan Sidney 1984: 7 dan 15).

Budaya politik yang demokratis yang bersifat terbuka, sangat berguna untuk mekanisme penyelesaian konflik. Tanpa budaya politik seperti itu, maka konsensus yang dirancang akan percuma karena tidak dilakukan dengan etika dan cara yang demokratis. Dalam konteks budaya politik demokratis perlu adanya pengetahuan bagi warga masyarakatnya tentang sistem politik kenegaraan. Di samping itu, perlu adanya keterkaitan emosional untuk menjaga etika demokratis, mekanisme tanggung jawab dari pemerintah dan masyarakat kepada pemerintah dan individu sebagai warga negara. Pengetahuan seperti itu harus disebarluaskan melalui berbagai cara, sehingga menjadi suatu kebiasaan yang mentradisi (Meyer 2002: 12).

Fenomena transisi dari suatu rezim otoriter-totaliter menuju pada rezim liberal-demokratis sudah menjadi topik pembicaraan di kalangan akademi dan pengkaji politik sejak pertengahan tahun 70--80-an. Salah satunya terkumpul dalam empat jilid buku hasil proyek penelitian yang disponsori oleh Woodrow Wilson International Center for Scholar. Proyek itu dipimpin oleh 
Guillermo O’Donnell dan kawan-kawan yang meneliti transisi demokrasi dan prospeknya di beberapa negara Amerika Latin dan Eropa Selatan. Buku yang berjudul Transisi Menuju Demokrasi: Tinjauan dari Berbagai Perspektif (1993) menekankan analisis komparatif yang memperlihatkan perbedaan kasus demokratis di beberapa negara sayap kanan yang sedang memasuki proses demokrasi. Menurut penulisnya kasus di beberapa negara di atas menunjukkan bahwa faktor internasional merupakan faktor sekunder, sedangkan faktor primer tetap berasal dari negara masing-masing. Gejala lain yang mendapat perhatian adalah adanya kontroversi antara teori dan kenyataan. Demokrasi yang dibentuk dari dalam lebih banyak berhasil dibanding demokrasi yang diimpor, sebab demokrasi yang diimpor tidak memperhitungkan faktor etnosentris yang sangat berpengaruh (O`Donnell 1993: xi--xvi).

Pendapatnya itu pada dekade tahun 1990-an menjadi tidak relevan lagi, sebab faktor internasional telah menjadi faktor penentu. Bahkan menjadi faktor utama dari perubahan yang terjadi di suatu negara, termasuk perubahan yang terjadi di Eropa Timur dan Rusia. Gejala perubahan domestik tersebut juga merupakan kecenderungan dari wabah gelombang demokrasi ketiga yang berasal dari pengaruh luar.

Sebagai ilustrasi, di tahun 60-70-an, Amerika Serikat sangat antusias membangun dan membantu kelompok militer di wilayah Amerika Latin. Tujuannya untuk menangkal bahaya komunisme yang sudah memengaruhi Kuba dan Bolivia. Berdasarkan tujuan tersebut Amerika Serikat seakan membiarkan terbentuknya pemerintahan militeri otoritarian di sebagian negara Amerika Latin. Akibatnya, banyak terjadi pelanggaran HAM yang dikhawatirkan memperlemah kondisi ke arah demokratisasi.

Kondisi demokratisasi di Amerika Latin dan Eropa Selatan sangat berbeda dengan kondisi demokratisasi yang terjadi di Eropa Tengah, Eropa Timur, dan Uni Sovyet (Rusia). Hal itu dinyatakan oleh Meyer dalam pandangannya bahwa menjelang akhir tahun 80-an, terdapat dimensi kebijaksan global, yakni suatu konsep untuk menata ulang pasar global dalam bidang sosial, ekologi, dan politik yang kerangka kerjanya mengarah pada prinsip kemitraan sejajar. Dimensi tersebut telah mendorong keperluan terhadap politik regional, yakni relevansi terhadap perubahan global, khususnya kerja sama regional. Kedua dimensi itu mendorong dan mempengaruhi dimensi kebijakan domestik, yakni menata ulang tatanan yang ada dengan merespon perubahan regional, dan global yang bergerak sangat cepat (Meyer 2002: 9 dan 12).

Dimensi regional telah mendorong parlemen Eropa untuk memperkenalkan persekutuan bagi keselamatan bersama di tempat yang dianggap sebagai sumber ancaman. Negara Eropa Barat ingin memberikan contoh dan peran yang signifikan bagi negara Eropa Timur, termasuk Uni Sovyet (Rusia). Proses konsepsi tersebut menunjukkan keinginan untuk menata dimensi regional ke arah demokratis, kerja sama keamanan, ekonomi, dan kemanusiaan dengan mengurangi ketegangan dan meningkatkan kesejahteraan bersama (Meyer 
2002: 202). Dengan demikian dapat dikatakan bahwa terdapat perbedaan model transisi demokrasi yang terjadi di Amerika Latin dan Eropa Selatan di tahun 60--70-an dengan model transisi demokrasi yang terjadi di kawasan Eropa Timur sekitar akhir tahun 90-an.

Sebelumnya dan di tempat lain tekanan pihak asing telah membentuk keseimbangan dan pengaruh yang berarti pada faktor domestik, khususnya bagi rezim militeris yang menekan gerakan pro demokrasi. Sebaliknya bagi negara-negara di kawasan Eropa Timur, tekanan pihak asing menguntungkan pihak pro demokrasi dan dampaknya merugikan pihak konservatif yang berbalik berperan sebagai pihak oposisi (Anderson 2001: 89).

Penelitian O`Donnell dan kawan-kawan dapat dikatakan sebagai kecenderungan gelombang demokrasi kedua setelah Perang Dunia keII. Padahal kecenderungan demokrasi terus meningkat dan meluas, setelah negara-negara komunis dianggap tidak berhasil menyejahterakan masyarakatnya. Berbagai negara dunia ketiga (Selatan) dan beberapa negara komunis Eropa Timur, berusaha melepaskan diri dari pengaruh rezim komunis internasional. Mereka kemudian beralih pada alternatif demokrasi.

Pada kesimpulannya disebutkan bahwa demokrasi senantiasa mengandung resiko kegagalan. Transisi tidak dapat diramalkan bagaimana kesudahannya. Sebab di dalamnya berkecamuk berbagai aspek dan faktor yang saling berkait dan bertentangan. Dengan kata lain, ketidakpastian dan kemungkinan akan selalu membayangi proses demokrasi di suatu negara. (O`Donnell 1993: 57).

Kesimpulan itu kemudian ditegaskan kembali, bahwa memang proses demokrasi tidak dapat diramalkan, khususnya di negara pasca komunis. Oleh sebab itu, teori demokrasi pun menjadi kompleks dalam menjajagi dan meramalkan proses tersebut. Sebab kemungkinan satu teori bisa ditrapkan di suatu negara, tetapi kemungkinan besar tidak dapat diterapkan di negara yang lain (Anderson 2001: 49).

Selain itu, praktik penetrasi rezim otoritarianisme-totalitarianisme yang telah berlangsung selama 70 tahun, seperti di beberapa negara Eropa Timur dan Rusia, dapat menyebabkan kegagalan dalam proses demokrasi. Mereka umumnya belum mampu mempersiapkan pranata dan infrastruktur yang memadai dan diperlukan secara singkat. Bahkan kondisi seperti itu sering menimbulkan konflik berkepanjangan dengan munculnya eforia, xenofobia, chauvinisme, dan frustasi yang dapat mengurangi proses ke arah demokrasi (Remnick 1997, Hikam 1999: 57, Lukin 1999: 39, dan Sorensen 2003: 80--83).

Jelas bahwa pembentukan suatu tradisi (demokrasi) membutuhkan waktu yang panjang. Berbagai negara yang memelopori ideologi demokrasi juga membutuhkan waktu yang lama untuk membentuk kesadaran dan nilainilai demokrasi dalam masyarakatnya. Demokrasi dapat dikatakan sebagai salah satu mekanisme pemicu konflik dan sekaligus mekanisme penyelesai konflik. Faktor pendukung demokrasi, seperti individualisme, liberalisme, egalitarianisme, dan kapitalisme merupakan faktor pemicu konflik. Akan 
tetapi, masyarakat, negara, dan pemerintahan yang demokratis juga harus mempunyai mekanisme dan perangkat untuk menyelesaikan berbagai konflik yang timbul akibat faktor di atas. Agaknya perlu adanya lembaga eksekutif, legislatif, yudikatif, media massa, dan lembaga lain sebagai sistem pengontrol kekuasaan. Sebabjika tidak adanya perangkat tersebut, konflik tidak pernah akan selesai, dan kestabilan sosial akan terganggu. Dari penjelasan di atas dapat dikatakan bahwa tanpa tradisi dan budaya politik demokrasi, demokrasi di suatu negara akan mengalami berbagai kendala.

Di negara Barat, proses liberalisasi mendahului demokrasi. Liberalisasi mengacu pada penetapan batas tugas negara untuk memberi ruang publik, baik bagi masyarakat maupun bagi individu. Ketika disandingkan dengan konsep demokrasi dapat berjalan seiring, tidak menimbulkan pertentangan yang berarti, bahkan menambah kekuatan dan menjadi pendorong bagi kehidupan bermasyarakat. Jadi, jika tanpa didahului dengan proses liberalisasi dan kesadaran atas hak individu, maka realisasi demokrasi akan berjalan lambat. Kedua konsepsi tersebut mendasari demokrasi dan membentuk saling ketergantungan satu sama lain (Chee 1994: 8).

Menurut Markoff, dalam mengantisipasi situasi transisi, kemungkinan para elite politik di kawasan Eropa Timur dan Rusia melihat model keberhasilan transisi dari negara lain dengan menggunakan teori kemiripan atau yang disebut sebagai The Theory of Organization Mimicry atau teori mengorganisir bentuk kemiripan. Teori itu digunakan oleh negara dalam berinteraksi dengan negara lain yang secara tidak langsung juga memengaruhi bentuk gerakan sosial yang ada di negara lain dan di negaranya sendiri (Markoff 2002: 59). Teori itu berproses dalam bentuk peniruan. Pertama, secara langsung atas berbagai konstitusi dari negara lain. Kedua, meniru model kesuksesan negara lain. Ketiga, adanya ketergantungan terhadap sumber daya di negara lain. Keempat, lingkungan sosial budaya yang menumbuhkan gerakan sosial. Kelima, pengaruh negara kaya yang menanamkan budaya mereka dengan berbagai cara, seperti pemberian bea siswa, pelatihan, dan perekutan (Markoff 2002: 61).

Kelima langkah tersebut umunya dilakukan oleh pemerintah baru pascakomunis di kawasan Eropa Timur dan Federasi Rusia. Proses langkah tersebut, pertama, mereka mengusahakan membuat konstitusi baru. Kedua, menggunakan model penyelesaian krisis perekonomian yang meniru beberapa negara Eropa Barat yang telah menggunakannya lebih awal. Ketiga, terpaksa harus menyerah menjadi klien dari lembaga keuangan internasional. Keempat, membuka kesempatan kepada masyarakatnya untuk berpartisipasi dalam berbagai bidang kehidupan, seperti dibukanya kesempatan privatisasi dan pembentukan organisasi sosial serta politik. Kelima, banyaknya bantuan yang diterima oleh negara di kawasan itu dari berbagai negara kaya dan maju yang mempunyai kepentingan ekonomi, politik, sosial, dan budaya. 


\section{TEORI TRANSISI DeMOKRasi}

Demokrasi merupakan satu kesatuan paket atau perangkat sistem pemerintahan yang berisi dan meliputi kebebasan individu (sebagai prinsip utama yang mendasar), pemilihan umum, pembagian kekuasaan, multipartai, partisipasi, kompetisi yang sehat dan adil, kompromi yang terjamin, penegakan hukum yang jujur dan adil, kebebasan bagi media massa, dan adanya transparansi serta pertanggungjawaban dari pemerintah. Semua perangkat tersebut di atas sebenarnya merupakan suatu bentuk pengakuan terhadap hak dan kepentingan antara individu, masyarakat, dan negara.

Baik negara demokrasi ataupun yang sedang memasuki transisi demokrasi dapat dilihat dan dinilai, apakah demokrasi negara tersebut berjalan baik, sangat baik, kurang baik, bersifat semu, terbatas, atau bahkan menjadi beku. Semua itu dapat dilihat dari perangkat yang terdapat di dalamnya, serta bagaimana cara pemilu, pembagian kekuasaan, sistem peradilan, kebebasan individu, kebebasan media, termasuk bagaimana negara tersebut memberikan ruang gerak bagi kegiatan para agensi. Perangkat tersebut juga menjadi bahan indikator bagi Freedom House, suatu lembaga yang mengkaji dan menilai berjalannya suatu sistem demokrasi di suatu negara. Setiap tahun mereka memberikan laporan kepada khalayak tentang data dan persentase demokrasi hak kebebasan di suatu negara (lihat pada laporan Freedom House dalam Karatnyky 1999: 124--125).

Dengan munculnya paradigma demokrasi, maka teori dan konsepsi tentang negara kembali diperdebatkan. Begitu juga sebaliknya, dengan munculnya fenomena prodemokrasi, khususnya di Eropa Timur dan Rusia, maka konsep dan teori tentang hubungan antara negara dengan masyarakat kembali ditinjau ulang. Peninjauan itu menghasilkan konsepsi tentang masyarakat sipil, ruang publik, dan gerakan prodemokrasi (Chandoke 2001: 9-10).

Masyarakat sipil mendapat porsi pembicaraan saat dihubungkan dengan konsepsi kenegaraan. Sebaliknya konsepsi kenegaraan tidak dapat dipahami, kecuali jika ditempatkan di dalam hubungannya dengan masyarakat sipil. Konsepsi masyarakat sipil sendiri dilandasi oleh tradisi liberal klasik yang ditandai dengan asas demokrasi. Suatu negara demokrat adalah negara yang tidak hanya dibatasi oleh konstitusi dan institusi parlemen, partai politik, dan kekuatan-kekuatan yang diorganisir yang menjadi milik dunia politik, tetapi juga dibatasi dengan dan oleh perkumpulan kehidupan yang berada di luar wilayah bidang pemerintah yang dikenal sebagai masyarakat sipil yang juga mempunyai hak berpolitik (Chandoke 2001: 36 dan 49).

Hak merupakan suatu yang pokok dan signifikan dalam kehidupan politik liberalis, sebab hak membicarakan persetujuan mendasar tentang bagaimana manusia seharusnya diperlakukan. Individu dalam konsepsi liberal memiliki berbagai hak pribadi yang perlu diatur keberadaanya dengan hak pribadi yang lain. Negara sekalipun tidak dapat mencampuri hak kebebasannya yang kemudian menjadi prinsip pokok dalam wacana politik liberal. Oleh sebab itu, individu mempunyai hak untuk diperlakukan sama oleh negara. Dalam 
arti, setiap individu sama di mata hukum. Bagi kaum liberalis, peran negara terbatas pada fungsi regulatif yang menyediakan kondisi dan ruang untuk kebebasan individu. Masyarakat sipil secara tidak langsung menyediakan ruang bagi setiap individu sebagai makhluk sosial bersama individu lainnya untuk dapat mencapai tujuan yang diinginkannya (Cassesse 1994, Puntsch 1998, Howard 2000, dan Bolkestein 2001, Chandoke 2001: 148--149, 283 dan 315).

Negara memainkan peranan paradoks dalam kehidupan individu dan masyarakat. Di satu sisi, negara adalah lembaga yang koersif, di sisi lain negara memberikan perlindungan dan keuntungan tertentu kepada anggotanya yang tidak dapat diberikan oleh lembaga lain. Peran yang kontradiktif itu menjadi polemik dan dilema untuk menentukan secara teoritis tentang negara, sebab peran yang mana yang dianggap primer dan sekunder, serta peran mana yang dapat diterima oleh kalangan prodemokrasi. Pandangan dari gerakan demokrasi, negara tidak dibenarkan untuk mengintervensi wilayah individu maupun wilayah masyarakat (Chandoke 2001: 53).

Transisi demokrasi dapat dilihat dari berbagai perspektif, antara lain dari perspektif peran kepartaian ( Holmes 1994: 309-330), pengaruh budaya politik (Almond dan Sidney 1984), kedudukan eksekutif dan parlemen (Remington 1994: 57--84), peran media massa dan masyarakat sipil (Clark 1995, Hikam 1999, dan Chandoke 2001). Di sisi lain transisi demokrasi juga dapat ditinjau dari perspektif partisipasi, kompetisi, dan kebebasan (Sorensen 2003), serta dari perspektif ruang gerak para agensi (sebagai pilar dalam demokrasi).

Pengamat lain dalam penelitiannya mengungkapkan bahwa kondisi demokrasi yang dihubungkan dengan kemampuan ekonomi, sudah dilakukan oleh para peneliti sekitar tahun 1960--1970-an, khususnya pada transisi demokrasi di wilayah Amerika Latin. Akan tetapi, teori tersebut diragukan setelah memasuki era tahun 1980--1990-an sebab pembangunan ekonomi yang meningkat ternyata tidak mengubah kualitas demokrasi, bahkan negara Amerika Latin dan sebagian Afrika masih bertahan pada sistem otoritarian yang dimonopoli oleh para junta militeris (Anderson 2001: 57). Sebaliknya pendapat yang mendukung bahwa kondisi negara maju dapat mendukung proses demokrasi muncul dari pengamat politik, seperti Prezewosky (1996) dan Huntington (2001).

Ada pengamat yang melihat demokrasi dari sudut kondisi sosial budaya. Faktor itu menurutnya memengaruhi jalannya demokrasi. Salah satunya adalah adanya keragaman etnik yang dikhawatirkan dapat menghambat demokrasi (Anderson 2001: 58). Keberhasilan demokratisasi terjadi di beberapa negara Eropa Timur, seperti Ceko dan Hongaria, karena mereka merupakan masyarakat yang homogen. Di beberapa negara pascakomunis berhasil mengimplementasikan sistem demokrasinya, sebab masalah mereka tidak sekompleks negara pascakomunis lain yang berciri masyarakat majemuk, seperti Rusia. 
Pendapat lain menyatakan bahwa agama Kristen Protestan lebih dapat menerima demokrasi daripada Katolik, Katolik Ortodok, dan Islam (Anderson 2001: 58). Budaya Protestanisme secara historis telah memberikan tempat dan ruang bagi kebebasan individu sehingga kemudian berkembang liberalisme, kapitalisme, dan demokrasi, seperti pernah diungkapkan oleh Max Weber. Dengan kata lain, bahwa selain Protestan, kepercayaan lain dianggap belum memberikan ruang gerak bagi para penganutnya untuk memasuki proses demokrasi.

Faktor internal lain adalah kondisi kesejarahan dan budaya (collective memories) pada suatu masyarakat dapat menjadi faktor penghambat ataupun pembuka jalan bagi demokrasi (Anderson 2001: 59). Hal ini juga bergantung pada budaya politik suatu masyarakat yang dapat memberikan peluang bagi proses demokrasi. Proses demokrasi di masyarakat pascakolonial maupun di negara pascakomunis dianggap mempunyai resistensi yang memerlukan waktu yang lama untuk mengubahnya.

Kondisi kemajemukan ideologi di suatu negara juga dapat menjadi ancaman demokrasi. Walaupun demokrasi memberikan peluang bagi terciptanya pluralisme dalam segala bidang, termasuk ideologi, keberagaman ideologi dapat mengancam proses demokrasi. Negara yang baru mengenal demokrasi akan selalu mengalami konflik internal dan belum mampu menyelesaikan konflik secara demokratis. Hal itu disebabkan infrastruktur dan mentalitas mereka belum mentradisi. Selain itu, bentuk pluralisme ideologi yang berkaitan dengan etnis dan agama juga dapat mengancam kelangsungan integrasi suatu negara.

Kondisi hubungan antara lembaga negara yang tidak sehat juga akan menjadi konflik dalam proses demokrasi. Hal itu dapat terjadi jika kekuasaan presiden terlalu berlebih atau sebaliknya, kekuasaan parlemen (oligarki politik) terlalu dominan menguasai jalannya pemerintahan (Anderson 2001: 59). Di sisi lain, kondisi krisis ekonomi juga dapat dianggap menjadi penyebab terhambatnya demokrasi (Anderson, 2001). Akan tetapi, pengamat lain berpendapat bahwa pemulihan krisis ekonomi yang cepat dapat mendorong demokrasi lebih baik (Anderson 2001: 59).

Kondisi perang, chauvinisme, dan munculnya nasionalisme radikal juga merupakan faktor yang dapat melemahkan demokrasi, sebab kondisi tersebut dapat menguras keuangan negara dan masyarakat. Kondisi itu terdapat dalam konteks transisi demokrasi di Rusia sepanjang tahun 1992-1999, sehingga menyebabkan seringnya terjadi konflik internal yang secara langsung menghambat proses demokratisasi di Rusia.

Sejumlah transisi sering menimbulkan kekacauan dan instabilitas yang dapat menimbulkan pengaruh negatif pada pelaksanaan demokrasi itu sendiri. Transisi tersebut disebabkan oleh kasus pergantian kepemimpinan atau kekuasaan. Ini berarti terjadinya perpindahan otoritas dapat menyebabkan lemahnya legalitas. Untuk memacu dan mengembalikan legalitas, biasanya pemerintah baru akan mengambil tindakan yang bertentangan dengan demokrasi. 
Demokrasi selalu diklaim oleh pemerintah sebagai atas nama rakyat. Klaim itu khususnya berkaitan dengan perlawanan terhadap suatu rezim, baik otokrasi, aristokrasi, maupun otoritarian. Sepanjang gelombang demokratisasi terjadi perdebatan mengenai demokrasi mana yang sesungguhnya yang baik. Konflik yang terjadi pada masyarakat demokrasi akan selalu dihadapkan pada gerakan anti-demokrasi, walaupun pihak anti-demokrasi tetap mengklaim dan mengacu pada prinsip demokrasi versi dan model mereka. Pendekatan itu bukan saja terjadi pada awal dan pertengahan abad 20, tetapi telah berlangsung sejak 200 tahun sebelumnya. Pada dekade abad 18, perdebatan terjadi di Eropa Barat antara kubu aristokrat dan kubu demokrat. Kubu aristokrat berpendapat bahwa dunia sosial pada dasarnya terbentuk oleh struktur yang tidak setara. Kolektivitas dilihat sebagai elemen sentral dari suatu masyarakat. Model masyarakat seperti itu disebut sebagai aristokrat. Sebaliknya kubu demokrat berpandangan bahwa pengaturan sosial didasarkan atas kebebasan dan kesetaraan individual. Masyarakat yang dibentuk dengan pandangan itu disebut berciri demokrat. Sejak abad ke-18 masyarakat menyatakan kehendaknya terhadap pemerintah aristokrat untuk menurunkan kekuasaan mereka melalui kontrak dengan masyarakat yang diperintah. Gelombang pemikiran itu muncul dan berkembang mulai dari Inggris, Koloni Inggris di Amerika Utara, Polandia, hingga Prancis (Markoff 2002: 3-5).

Dalam periode panjang $1780-1910$ terdapat pergulatan yang menghasilkan bentuk pendemokrasian. Pertama, perjuangan untuk mendapatkan otoritas bagi parlemen terpilih. Kedua, perjuangan untuk mendapatkan perluasan atas hak memilih. Ketiga, perjuangan untuk menghubungkan antara kekuasaan dengan subyek pemilih. Keempat, perjuangan untuk mengadakan Pemilu. Kelima, perjuangan untuk pembentukan partai politik. Keenam, perjuangan untuk terbentuknya emansipasi publik dan komunitas tertentu. Setelah Perang Dunia ke-II, beberapa negara monarki runtuh, beberapa negara yang dahulu diperintah oleh sistem monarki bergegas mengubah ke sistem demokrasi. Terlebih setelah Perang Dunia ke-II dengan ditaklukannya fasisme, banyak negara beralih memilih model demokrasi, walaupun model ini mendapat saingan yang setara dengan model komunis. Kedua model tersebut digunakan oleh masyarakat jajahan untuk membebaskan dirinya dari kungkungan kolonialisme dan imperialisme. Jadi model dan gerakan aksi sosial prodemokrasi yang menggugat sistem atau rezim demokrasi sudah berlangsung lama. Kaum Bolshevik pun termasuk gerakan sosial yang menggugat model teokratis-aristokratis di Rusia (Markoff 2002: 6-9 dan 51-52).

Setelah perang dingin, demokrasi yang menonjol berasal dari tradisi liberal yang dipengaruhi oleh pemikiran Bentham, Stuart Mill, Rousseau, dan Von Hayek yang mempertanyakan dan menekankan pada sistem politik demokrasi dengan tiga unsur dasar, yaitu partisipasi, kompetisi, dan kebebasan (Sorensen 2003). Sedangkan demokrasi dari pemikiran Marxis yang sebelumnya populer menjadi dijauhkan oleh banyak negara. 
Jika pada tahun 70-an proses demokrasi berjalan lambat, maka pada tahun 90-an proses demokrasi berlangsung sangat cepat yang ditandai dengan runtuhnya rezim komunis dan berakhirnya konfrontasi antara dua blok. Pada proses itu hanya Rumania yang mencoba bertahan dari gerakan sosial pro demokrasi. Setelah itu gerakan yang sama ikut menyumbang dalam membubarkan Uni Sovyet (Brzezinski 1990, dan Markoff 2002: 18). Di samping itu, klaim demokrasi kemudian menjadi kecenderungan dan keinginan untuk mendapatkan respek di dunia internasional, seperti juga akhirnya dilakukan oleh negara di kawasan Eropa Timur dan Federasi Rusia (Markoff 2002: 174).

Bahkan setelah runtuhnya komunis, negara di Eropa Tengah dan Timur segera mengumumkan keinginan untuk membangun format model demokrasi melalui mekanisme Pemilu, pembentukan partai, dan parlemen yang bebas, sebab tindakan itu juga menjadi syarat yang ditawarkan oleh pihak Bank Dunia dan International Monetary Fund (IMF). Jadi demokrasi telah menjadi trend wacana yang menggejala pada akhir tahun 1980-an dan awal tahun 1990-an di berbagai masyarakat dunia dengan menyisihkan wacana filosofis lainnya (Markoff 2002: 190).

Krisis ekonomi dan sosial menjadi faktor dalam sebagian besar transisi demokrasi yang terjadi di Eropa Timur. Transisi di sana menjadi signifikan, karena harus berlangsung dalam konteks perubahan besar pada struktur ekonominya, apalagi tidak pernah ada model reformasi ekonomi yang jelas dapat digunakan di negara tersebut. Tiga tahap reformasi ekonomi di negara Eropa Timur (1) pasar tertutup menjadi pasar terbuka, (2) ekonomi terencana dan terpusat menjadi ekonomi pasar bebas, (3) perusahaan negara (kolektif) menjadi perusahaan pribadi atau swasta (privatisasi) (Sorensen 2003: 97).

Dari beberapa kasus didapat kenyataan bahwa otoritarianisme tidak dapat langsung ditinggalkan dalam transisi demokratisasi. Sebab membutuhkan waktu dan proses yang panjang dengan aktor agensi yang berada di tengah dan tanpa diketahui hasilnya secara pasti. Selama masih ada kelompok mayoritas dan lembaga yang kuat, seperti militer di Amerika Latin, sebagian negara Asia dan Afrika atau masih bercokolnya elite nomenklatura di Eropa Timur dan Rusia, maka demokrasi belum dapat dikatakan kuat sepenuhnya, sebab mereka dapat saja menveto atau mengelak dari kepentingan yang dibuat secara demokratis sekalipun. Demokrasi yang demikian menjadi terhambat dan terbatas karena tidak memberi peluang bagi kompetisi, partisipasi, dan kebebasan pihak lain (Sorensen 2003: 69, 80, dan 83).

Menurut Chee, untuk mencapai demokrasi, setiap negara dan masyarakat umumnya melalui proses transisi yang sangat berat dan bertahap, walaupun tatanan negara sudah demokrasi, akan tetapi tidak ada demokrasi di negara manapun yang sempurna, termasuk di Amerika (Chee 1994: 4).

Hampir di tiap negara proses transisi demokrasi berjalan secara bertahap. Tahap I tranformasi (reforma) yang terjadi ketika elite yang berkuasa mempelopori proses perwujudan demokrasi. Tahap II berupa replacement 
(ruptura) terjadi ketika kelompok oposisi memelopori proses perwujudan demokrasi dan rezim otoriter tumbang atau digulingkan. Tahap III transplacement (rupforma) terjadi apabila demokratisasi terutama merupakan hasil tindakan bersama kelompok pemerintah dan kelompok oposisi (Huntington 2001:146 lihat juga Borneman 1997: 8-10 dan 140-142).

Transisi dapat berjalan apabila kelompok pembaharu lebih kuat dari pada kelompok konservatif, jika pemerintah baru lebih kuat dari pada kelompok oposisi dan jika kelompok moderat lebih kuat daripada kelompok ekstremisradikal. Dengan kata lain, transisi mensyaratkan pemerintah baru harus lebih kuat secara legitimasi daripada oposisi (Huntington 2001: 158).

Sorensen mengkaji transisi demokrasi dari beberapa tahap, yakni (1) tahapan persiapan, ditandai dengan perjuangan politik yang bergerak untuk melawan dan menghancurkan rezim non-demokrasi, (2) tahapan keputusan, yakni menertibkan berbagai elemen demokrasi, (3) tahapan konsolidasi, yakni memberdayakan demokrasi secara praktikal (Sorensen 2003: 109).

Huntington mencatat ada beberapa masalah transisi yang harus dihadapi dan dilakukan oleh pemerintahan demokrasi baru yang berkuasa, yakni (1) memapankan konstitusi baru, (2) mengadakan pemilu, (3) menyingkirkan para penjabat orde lama, (4) mencabut undang-undang kadaluwarsa dan bertentangan dengan HAM, (5) mengubah lembaga otoriter, seperti polisi, pengadilan dan intelejen, (6) mengembalikan aset negara, (7) memperkecil keterlibatan militer di pemerintahan, (8) menangani pelaku kejahatan di masa lalu. Selain itu, pemerintah baru juga akan menghadapi masalah krusial lainnya, seperti pemberontakan, konflik komunal, kemiskinan, inflasi, dan hutang luar negeri (Huntington 2001: 272--273). Secara garis besar transisi demokrasi di sebagian kawasan Eropa Timur dan Rusia mengalami dan menghadapi berbagai masalah yang dikemukakan oleh Huntington dan beberapa penulis di atas.

Di lain pihak, terdapat pandangan yang menyatakan bahwa kemungkinan alasan mendasar ketidakstabilan rezim demokrasi baru, karena lemahnya legitimasi dan rendahnya keefektifitasan pemerintah. Padahal kestabilitasan suatu rezim tergantung pada kemampuan kelompok elite politik, kemampuan para pemimpin partai, kemampuan para pemimpin dunia usaha untuk bekerja sama dan mengakomodir kepentingan mereka dengan menahan diri untuk tidak berseberangan, akan tetapi yang sering terjadi justru sebaliknya (Linz dan Lipset dalam Huntington 2001: 332--333).

Masalah lain yang perlu diperhatikan dalam transisi demokrasi adalah bahwa transfer demokrasi dari budaya Barat ke negara lain sering mengalami kesulitan, alasannya. (1) sifat kebudayaan demokrasi itu sendiri yang tidak nampak, seperti pada hubungan interaksi antara elite politik, tanggung jawab masyarakat, partisipasi dan inisiatif sebagai norma tingkah laku masyarakat Barat yang sulit dipraktikan dalam kebudayaan negara lain, (2) kendala birokratisme otoriter yang sangat dominan, sehingga menghambat tranformasi teknologi dan pemerintahan teknokratis. (Almond dan Sidney 
1984: 4-5). Dalam kasus di sebagian negara Eropa Timur dan Rusia, hambatan di atas juga terdapat dan yang secara langsung telah menghambat pelaksanaan demokrasi.

Dalam diskursus transisi demokrasi juga dapat dilihat hubungan antara kedudukan masyarakat sipil dengan negara. Dalam kaitan itu, Clark berpendapat bahwa jika masyarakat sipil kuat dan mampu berhadapan dengan negara, maka demokrasi dianggap berhasil. Sebaliknya jika negara kuat dan masyarakat sipil lemah, maka demokrasi dianggap belum berhasil. Jadi dapat dikatakan bahwa masyarakat sipil merupakan hakikat dari masyarakat politik yang membutuhkan ruang publiknya. Berkaitan dengan itu, gerakan pro demokrasi berusaha untuk memberdayakan potensi masyarakatnya dan membuka ruang gerak mereka, agar terwujud masyarakat sipil yang demokratis dan pluralis yang menyadari akan hak dan kepentingannya (Clark 1995).

Kehadiran masyarakat sipil yang dimotori oleh gerakan pro demokrasi sesungguhnya diharapkan dapat menjadi pengimbang kekuatan negara sekaligus pengembang pertisipasi masyarakat dengan berbagai usaha seperti mengkritik, memonitor, mengontrol, mencegah intervensi, monopoli, dan hegemoni negara terhadap hak individu dan masyarakatnya. Wacana masyarakat sipil memasuki perbendaharaan teori politik, bahwa suatu komunitas sosial mampu mengorganisir dirinya secara independen dari tujuan spesifik yang tidak ditentukan oleh negara. Kebebasan masyarakat sipil membentuk bagian terpenting dari gerakan demokrasi pada abad ke-18 di Eropa Barat melawan pemerintahan absolut (Gellner 1995 dan Chandoke 2001). Pemikirannya itu didasarkan bahwa harkat individu perlu diberi bobot kebebasan sebagai hak dasar manusia secara alami, sedangkan negara tidak dibenarkan untuk mengintervensi wilayah individu (privat) maupun wilayah masyarakat (publik). Jadi pada intinya konsepsi demokrasi dan masyarakat sipil merupakan hakikat dari masyarakat politik yang menentang dan mengkritik gagasan hubungan atas-bawah antara negara dan masyarakat, seperti yang terjadi dalam negara komunis. Oleh sebab itu, mereka berusaha memperjuangkan untuk membatasi wilayah negara sekaligus memperluas wilayah nonnegara (wilayah privat dan wilayah publik).

Pemberdayaan demokrasi dan masyarakat sipil pada masa transisi demokrasi di kawasan Eropa Timur dan Rusia dianggap oleh sebagian kalangan sebagai proyek demokrasi neoliberal dari negara Kapitalisme Barat yang didasarkan pada pengembangan privatisasi, denasionalisasi, dan deregulasi yang berusaha mengambil alih sebagian peran negara yang telah berlebihan mengkooptasi masyarakatnya. Tujuannya adalah tersedianya pasar terbuka yang dapat memberikan akses kepada pihak luar untuk menanamkan modalnya dan menyalurkan produk industrinya ke negara yang bersangkutan, sehingga Wallerstein dan Spar mencurigai bahwa redemokrasi dalam negara Eropa Timur (Rusia) adalah mekanisme penyesuaian bagi keterlibatan yang semakin dalam serta partisipasi yang semakin meluas di 
dalam kerangka sistem kapitalis internasional (Wallerstein dalam Hikam 1999: 40 lihat juga Spar 1998).

Berdasarkan kenyataan realitas sosial, politik, dan historis di atas, rekonstruksi dan analisis transisi demokrasi di suatu negara perlu dikaitkan dengan aspek politik-ekonomi global, sebab suatu rezim sayap kanan yang sedang menuju transisi demokrasi, umumnya selalu mengadakan kerja sama dengan teknokrat, birokrat, dan pemilik kapital dalam dan luar negeri (Gilpin 1987, O`Donnell 1993, Korten 1997, dan Petras 2001).

Perpindahan suatu rezim pada pascakomunis belum dapat dianggap memadai untuk menuju transisi demokrasi, seperti di sebagian negara kawasan Eropa Timur dan Rusia. Perpindahan seperti itu akan memakan waktu lama, terlebih lagi bagi negara dan masyarakatnya yang belum mengenal tradisi demokrasi. Proses tersebut ditandai dengan ditemukannya berbagai pelanggaran demokrasi, sebab infrastruktur dan mentalitas kebanyakan masyarakatnya belum memahami makna demokrasi. Kondisi dan fenomena tersebut telah mengkhawatirkan negara Eropa Barat. Mereka khawatir bahwa kondisi yang buruk dari pelaksanaan demokrasi di kawasan itu akan berdampak pada stabilitas ekonomi, politik, keamanan, dan sosial di kawasan Eropa. Atas dasar itu, mereka juga ikut memonitor sekaligus membantu pelaksanaan demokrasi di negara Federasi Rusia.

Faktor lain, seperti politik dan ekonomi merupakan faktor yang selalu saling melengkapi dan bersifat resipokral. Keduanya merupakan konsekwensi yang tidak dapat dihindari. Oleh sebab itu, sering terjadi konflik krusial dalam menjembatani antarkeduanya dalam masa transisi di berbagai negara (Gilpin 1987: 4, Brilmayer 1994: 61 -63, dan Hettne 1996: 2-5). Jadi bahwa tiap faktor yang direformasi saling terkait dan berhubungan satu sama lain, sehingga tidak mungkin berhasil mereformasi salah satu bagian jika faktor yang lain tidak disertakan dalam program pemulihan, baik ekonomi, terlebih lagi di bidang politik. Dengan kata lain, dapat dikatakan, bahwa reformasi ekonomi dan politik juga harus dilihat sebagai suatu kesatuan sistem dari tujuan transisi demokrasi.

\section{KESIMPULAN}

Teori tentang transisi demokrasi akan selalu berkaitan dengan berbagai faktor lain, seperti lamanya rezim otoriter berkuasa, luas geografi wilayah kekuasaan, struktur masyarakat, sistem pemerintahan, budaya politik, mentalitas/kesadaran masyarakat, hubungan antarkomunitas atau kelompok, penetrasi negara lain, peran dan hubungan dengan agensi luar negeri, serta gerakan kaum elit setempat. Alasannya, karena berbagai faktor sangat berpengaruh bagi pertumbuhan demokrasi di suatu negara, terlebih lagi pada masa transisi.

Para pengkaji transisi demokrasi melihat bahwa beberapa indikator jalannya suatu transisi demokrasi dapat dilihat dan dirujuk pada pelaksanaan dan mekanisme pemilu yang bebas dan berkala, adanya lembaga perwakilan 
rakyat yang terpilih, adanya agen demokrasi, seperti media pers yang bebas dan bertanggung jawab, adanya ornop yang diberi ruang gerak, adanya partai politik, adanya masyarakat sipil, dan yang mendasar lainnya adalah adanya pengadilan yang transparan, jujur, dan adil.

Fenomena historis dan berbagai aspek realitas, seperti peran agensi, struktur sosial, bentuk pemerintahan, mentalitas masyarakat, dan keberadaan pekerja media massa pada dasarnya mempunyai keterkaitan dan saling ketergantungan satu sama lain yang dapat membentuk satu kesatuan teoritis. Sebaliknya, beberapa teori transisi demokrasi juga berasal dan terbentuk dari adanya fenomena dan konteks perubahan sosial politik yang terjadi di beberapa negara, yang di dalamnya saling terkait satu aspek dengan aspek lainnya.

Konsepsi demokrasi yang di dalamnya terdapat unsur liberalisme, kapitalisme, pluralisme, kompetisi, dan privatisisme, dianggap lebih berhasil dibanding dengan konsepsi ideologi lain. Buktinya kini demokrasi dengan aspek yang menyertainya, tidak lagi menjadi sesuatu yang diharamkan bagi negara di kawasan Eropa Timur dan Rusia. Sebab lain, konsepsi itu diterima negara-negara itu adalah karena gelombang demokrasi dan kapitalisme juga tidak dapat dihindari oleh mereka yang waktu itu mengalami keterpurukan, akibat kesalahan manajerial di bidang politik, ekonomi, sosial, dan budaya. Dengan demikian dapat dikatakan bahwa demokrasi merupakan pilihan, setelah ideologi pilihan mereka mengalami stagnasi yang berkepanjangan. Berkembangnya kesadaran demokrasi kawasan itu, disebabkan juga oleh tuntutan dan kebutuhan dari adanya pergolakan secara global dan regional di wilayah Eropa Barat, Tengah, dan Timur yang mengarah pada keinginan dalam perbaikan sistem pemerintahan, kebutuhan untuk mengadakan kerja sama di bidang ekonomi, dan stabilitas keamanan yang bertujuan untuk kesejahteraan bersama. Mau tidak mau, negara di kawasan itu dipaksa dan terpaksa harus menerima suatu tuntutan perubahan di segala bidang kehidupan mereka, termasuk menerima konsepsi demokrasi secara bertahap.

Untuk keperluan itu dibutuhkan adanya reformasi demokrasi di bidang politik, ekonomi, sosial, dan budaya, dengan melakukan serangkaian tindakan, seperti mempersiapkan pasar kapitalisme (pasar terbuka dan bebas) yang menuntut adanya transparansi, jaminan pelaksanaan hukum, kebiasaan untuk melakukan tradisi bisnis perdagangan secara efisien, serta dukungan dari institusi pemerintah yang dapat dipercaya. Semua itu menurut para pengamat perlu direncanakan dan dibantu untuk mendorong pertumbuhan ekonomi negara kawasan itu ke arah yang lebih baik dengan mengurangi krisis ekonomi dan meningkatkan investasi. Hal itu didasari oleh pemikiran bahwa pertumbuhan dan tatanan ekonomi yang baik dapat mendorong dan membentuk transisi demokrasi ke arah yang lebih baik.

Demokratisasi merupakan suatu konsep yang akan selalu berkaitan dengan unsur perangkat demokrasi, seperti kebebasan individu dan masyarakat, partisipasi sosial politik, supremasi di bidang hukum dengan penegakan rule 
of law, kompetisi yang adil dan terjamin, kesadaran akan adanya pluralisme, serta pemilu yang bebas dan terjamin. Oleh sebab itu, dalam mengkaji transisi demokrasi perlu kiranya melihat beberapa faktor penghambat, di antaranya adalah, batas geografi yang luas dan jumlah populasi penduduk yang beragam, sebab dalam kondisi seperti itu cenderung akan sering memunculkan konflik yang didasarkan atas perbedaan dari berbagai aspek kehidupan di masyarakatnya, seperti, etnik, agama, batas wilayah, dan sumber daya. Lamanya pemerintahan otoritarian-totalitarian berkuasa yang juga menjadi penghambat demokrasi. Hal lain yang perlu diperhatikan adalah populasi masyarakat antara yang anti terhadap demokrasi dan yang prodemokrasi. Selain itu, tentunya adalah memperhatikan berbagai krisis ekonomi, sosial, dan politis dalam masa transisi demokrasi yang secara teoritis dapat menjadi hambatan bagi suatu proses transisi demokrasi untuk berkembang.

Dalam diskursus teori transisi demokrasi di bagian analisis diperlihatkan bahwa ciri demokrasi tidak hanya dapat dilihat dari adanya cheks and balances, multi partai, pemilu, partisipasi, dan masyarakat sipil, tetapi juga dapat dilihat dari adanya ruang gerak yang diberikan pemerintah kepada para agensi, seperti praktisi hukum, media massa, mahasiswa, dan organisasi sosial. Transisi demokrasi dapat dikatakan beku, semu, tersendat, terbatas, kurang baik, atau baik, bergantung pada dan dapat dilihat pada keberadaan ruang gerak yang diberikan oleh negara (pemerintah) dan masyarakat kepada para agensi itu, sebab konsekuensi dari demokrasi adalah perlu memberikan dan menyediakan peluang atau ruang gerak kepada para agensi untuk berpartisipasi, berkompetisi, sesuai dengan ruang lingkup kebebasannya. Pemberian ruang partisipasi bagi agensi dapat menjadi salah satu indikator teoritis untuk melihat jalannya demokrasi

Sampai sekarang masih terdapat masalah yang berkaitan dengan teori transisi demokrasi yang terus diperdebatkan dalam kancah akademis dan praktisi. Masalah itu berkaitan dengan pemahaman dan penerimaan demokrasi di berbagai negara yang sedang memasuki transisi demokrasi. Didasarkan oleh adanya konteks budaya, menyebabkan implementasi teori transisi demokrasi di setiap negara menjadi berbeda-beda, termasuk di Indonesia. Berbagai kasus di berbagai negara yang sedang memasuki masa transisi demokrasi dapat dijadikan kajian bandingan untuk melihat proses dan hambatan transisi demokrasi yang terjadi dengan melihat penerapan beberapa teori yang relevan. Selain itu, dengan mempelajari dan membandingkan model transisi demokrasi yang dijalankan di beberapa negara itu, dapat dilihat kelebihan dan kekurangannya, termasuk ciri khas demokrasi dari masing-masing negara bersangkutan.

\section{DAFTAR ACUAN}

Almond, Gabriel A. dan Sidney Verba. 1984. Budaya Politik: Tingkah Laku Politik dan Demokrasi di Lima Negara. Diterjemahkan oleh Sahat Simamora. Jakarta: Bina Aksara.

Anderson, Richard D Jr., et al. 2001. Postcommunism and The Theory of Democracy. Princeton: Princeton University Press. 
Bolkestein, Frits. 2001. Liberalisme in a Changing World. Published by The International Office of the Party for Freedom and Democracy and Liberal International, the Hague the Netherland.

Borneman, John. 1997. Settling Accounts: Violence, Justice, and Accountability in Postsocialist Europe. Princeton: Princeton University Press.

Brilmayer, Lea. 1994. American Hegemony: Political Morality in A One Superpower World. New Haven: Yale University Press.

Brzezinski, Zbigniew. 1990. Kegagalan Besar: Muncul dan Runtuhnya Komunisme di Abad Kedua Puluh. Diterjemahkan oleh Tjun Sujarman. Bandung: Rosdakarya.

Burke, Peter. 1992. History and Social Theory. Cambridge: Polity Press.

----.. 2001. Sejarah dan Teori Sosial. Diterjemahkan oleh M. Zed \& Zulfani. Jakarta: Yayasan Obor Indonesia.

Cassesse, Antonio. 1994. Hak Asasi Manusia di Dunia yang Berubah. Diterjemahkan oleh AR Zainudin. Jakarta: Yayasan Obor Indonesia.

Chandoke, Neera. 2001. Benturan Negara dan Masyarakat Sipil. Yogyakarta: Istawa dan Tiara Wacana.

Chee, Chang Heng. 1994. "Model Demokrasi Asia: Evolusi dan Implementasinya", dalam Demokrasi dan Kapitalisme: Perspektif Asia dan Amerika. Jakarta: Cides.

Clark, John. 1995. NGO dan Pembangunan Demokrasi. Diterjemahkan oleh Godril D. Yuwono. Yogyakarta: Tiara Wacana.

Gellner, Ernest. 1995. Membangun Masyarakat Sipil. Diterjemahkan oleh Ilyas Hasan. Bandung: Mizan.

Gilpin, Robert and Jean M. Gilpin, 1987. The Political Economy of International Relation. Princeton University Press.

Hettne, Bjorn (ed). 1996. “Introduction: The International Political Economy of Tranformation” dalam International Political Economy: Understanding Global Disorder. New York.

Hikam, Muhammad. 1999. Demokrasi dan Civil Society. Jakarta: LP3ES.

Howard, Rhoda E. 2000. HAM: Penjelajahan Dalih Relativisme Budaya. Diterjemahkan oleh N. Katjasungkana). Jakarta: Grafiti.

Holmes, Leslie. 1994. "Russia, Communism, Democracy", dalam Development in Russian and Post-Soviet Politics. (White, Stephen, et al). London: MacMillan.

Huntington, Samuel. P. 1994. “Demokrasi Amerika dalam Hubungannya dengan Asia”, dalam Demokrasi dan Kapitalisme: Perspektif Asia dan Amerika. Jakarta: Cides.

-----. 2001. Gelombang Demokrasi Ketiga. Diterjemahkan oleh Asril Marjohan. Jakarta: Grafiti.

Karatnycky, Adrian. 1999. "The 1998 Freedom House Survey: The Decline of Illiberal Democracy". Journal of Democracy. Vol. 10, No.1, Januari.

Korten, David C. 1997. When Corporations Rule the World: Bila Korporasi Menguasai Dunia. Diterjemahkan oleh Agus Maulana. Jakarta: Profesional Books.

Lukin, Alexander. 1999. "What When Wrong Russia?: Forcing the Pace of Democratization", dalam Journal of Democracy, April, Vol 10, No 2. John Hopskin University Press.

Markoff, John. 2002. Gelombang Demokrasi Dunia: Gerakan Sosial dan Perubahan Politik Diterjemahkan oleh Ari Setyaningrum. Yogyakarta: Pustaka Pelajar Offset.

Meyer, Thomas. 2002. Demokrasi Sosial Modern: Globalisasi dan Regionalisasi. (Karya Terjemahan). Jakarta: Fredrich Ebert Stiftung.

O'Donnel, Guillermo, et al. 1993. Transisi Menuju Demokrasi: Tinjauan Berbagai Perspektif. Jakarta: LP3ES.

Petras, James. 2001. "Globalisasi Sebuah Perspektif Sosialis" dalam Mcglobal Gombal. Diterjemahkan oleh Ken Budha Kusumawardhani dan Sutardji. Yogyakarta: Cubuc.

Puntsch, Eberhard. 1996. Politik dan Martabat Manusia. Jakarta: Sinar Harapan.

Remington, Thomas E. 1994. "Represesentative Power and the Russian States", dalam Developments in Russian and Post-Soviet Politics (White, Stephen, et al). London: MacMillan. 
Remnick, David. 1997. “Can Russia Change?", dalam Foreign Affair. January/February Vol 76, Number 1.

Sorensen, George. 2003. Demokrasi dan Demokratisasi: Proses dan Prospek dalam sebuah Dunia yang Sedang Berubah. Diterjemahkan oleh I Made Krisna. Yogyakarta: Pustaka Pelajar.

Spar, Debora L. 1997. “The Spotlight and the Bottom Line: How Multinational Export Human Rights", dalam Foreign Affair, Vol 77, No 2. Maret/April Press. 